\title{
TRITIUM RELEASE FROM A NONEVAPORABLE GETTER-PUMP CARTRIDGE EXPOSED TO MOIST AIR AT AMBIENT TEMPERATURE
}

\section{T. J. Biel}

A. E. Sherwood

M. F. Singleton

R. M. Alire

July 10,1979

$W$-rk performed under the auspices of the U.S. Department of

Energy by the UCLLL under contract number W-7405-ENG-48. ti:.

\section{4 \\ LAWRENCE LIVERMORE LABORATORY}

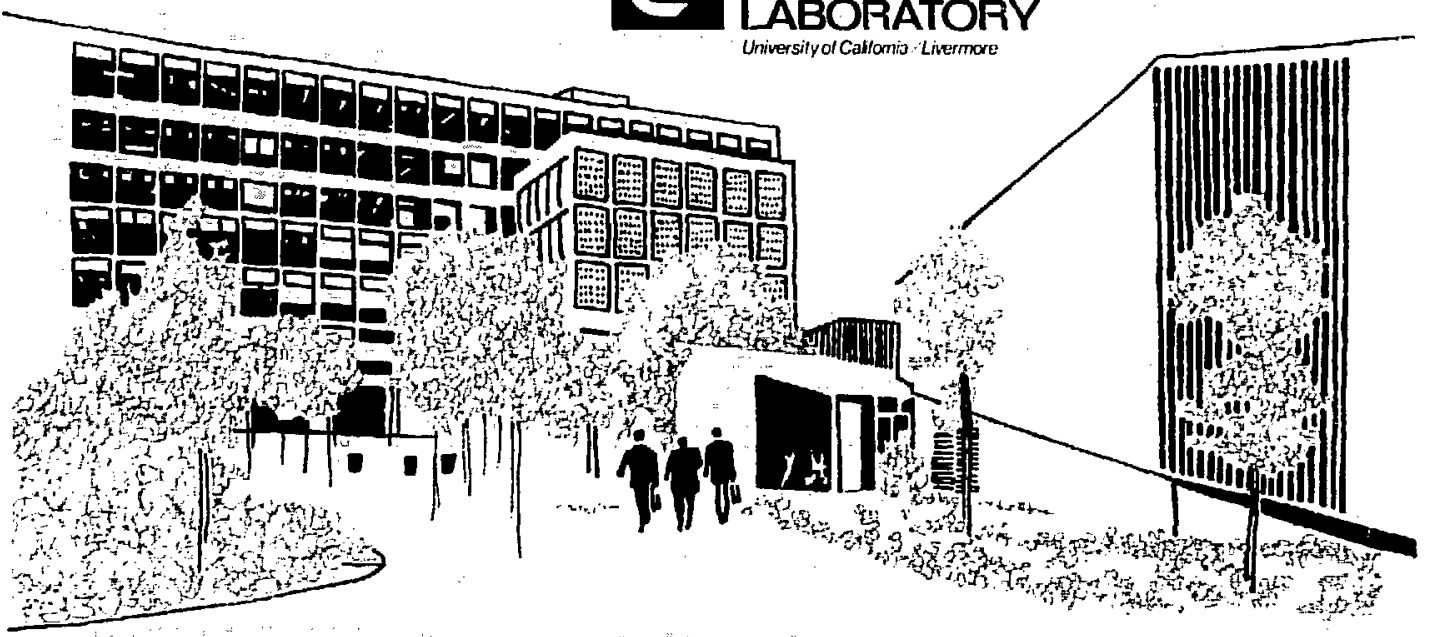

? 


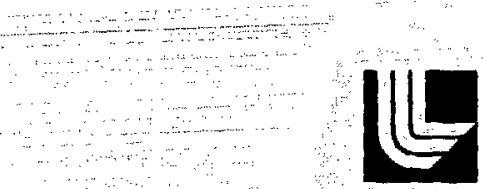

LAWRENCE LNERMORE LABORATORY

University of Caffornia Livermore, Califomia 94550

\section{TRITIUM RELEASE FROM A NONEVAPORABLE GETTER-PUMP CARTRIDGE EXPOSED TO MOIST AIR AT AMBIENT TEMPERATURE}

T. J. Biel

A. E. Sherwood

M. F. Singleton

R. M. Alire

Manuscript date: July 10, 1979 


\section{CONTENTS}

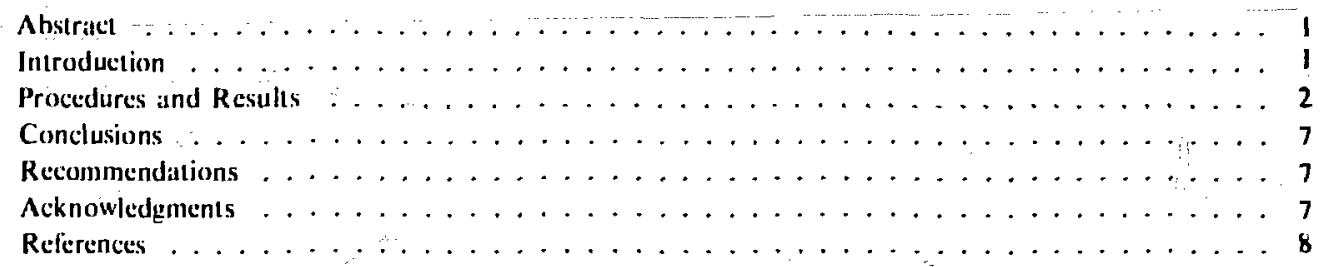




\section{TRITIUM RELEASE FROM A NONEVAPORABLE GETTER-PUMP CARTRIDGE EXPOSED TO MOIST AIR AT AMBIENT TEMPERATURE}

\section{ABSTRACT}

We measured the amount of tritium released when a commercially available getler-pump cartridge was exposed to moist air at a mbient temperatures. The cartridge consisted of $\mathrm{Zr}-\mathrm{Al}$ powder pressed onto an iron substrate, which is the type of cartridge proposed for use in the Tokomak Fusion Test Reactor. While we found that the initial release of tritium was rapid, the total activity released was less than $0.005 \%$ of the cartridge loading. Of this anount, at least $80 \%$ was released as tritiated water.

\section{INTRODUCTION}

Although the potential problems of tritium technology associated with fusion realtor systems have been anticipated for some time 12 fusion test facilities that use tritium as fucl are now being butlt; concepts are becoming realities Handling this highly radioactive hydrogen isotope safely and economicilly requires knowing how well the proposed components will function during routine sperations and knowing the consequences of unexpected liailures.

One component proposed for use in the Tokomak Fusion Test Reactor (TFTK) currently under construction at the Princeton Plasma Physics Laboratory is a commercially available getter pump. [The pump and cartridges are manufactured by Societal $\Lambda$ pparicci Elettrici e Scientifici (SAES). Italy, and distributed in the U.S. by Westinghouse Electric Corp. and SAES Gelters/USA.] This pump backs up turbomolecular punps, which remove residual tritium and deuterium from the torus after each burn, and services neutral-beam injectors. Previous investigations conducted at Lawrence Livermore Laboratory (LLL) deternined the pumping speed of tritium, the effects of impurities on pumping speed, and the equilibrium base pressures at loadings anticipated in the TFTR: ${ }^{4}$ The present investigation determined the amount of tritium releused when a tritium-loaded cartridge was exposed to moist air at ambient temperature.

The gettei pump consists of a $\mathrm{Zr}-\mathrm{Al}$ cirriridge. a heater, and an outer case with cooling-water coils

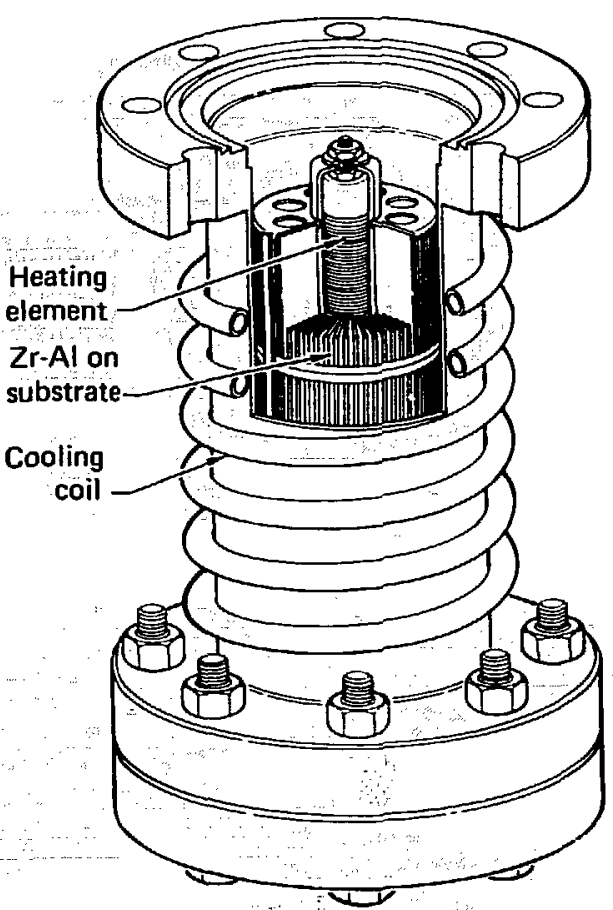

FIG. 1. SAES getter pump in stainless steel outer container with cooling coils.

(Fig. 1). (An unenclosed pump, consisting of only a cartridge and heater mounted on a flange, is called a nude pump.) The cartridges are made by pressing a 


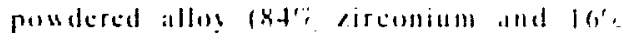

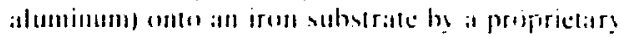

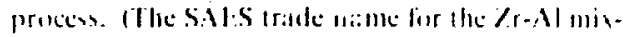

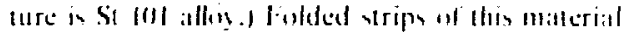

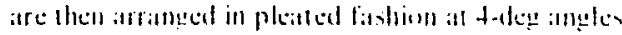

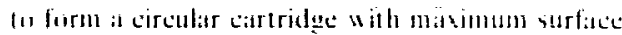

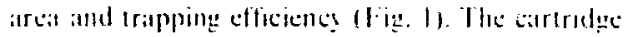
lice aroutal a roul-shaped heating elentent that in

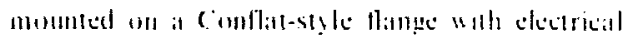

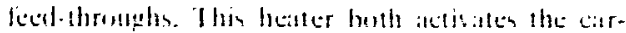

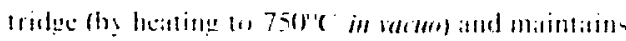
the pump at a desired aperatimg temperattere: ap. limulu lamperatures stepend on the particular an-

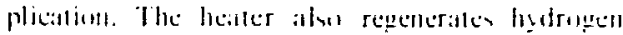
pumps lable I list the matalatarer, perfor-

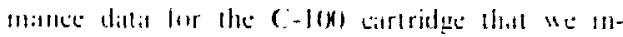

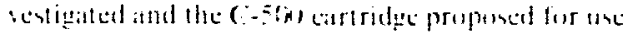
wh Wh II IR.

TABLE 1. Cartridge performance."

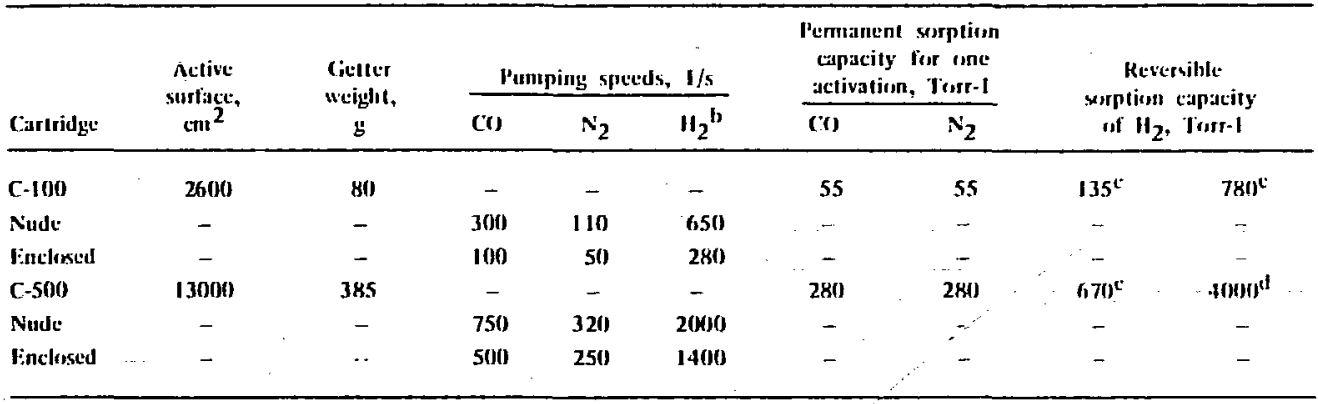

Data from Ref. 6.

blydrogeri pumping speed at 400$)^{2} \mathrm{C}$.

"Equilihrium pressure: $3 \times 10^{-6}$ al $400 \mathrm{C}$.

Jiquilibrium pressure: $1 \times 10^{-4}$ at 400$)^{\prime} \mathrm{C}$.

\section{PROCEDURES AND RESULTS}

We ativaled all enclosed SAES C-HOO getter pump cirtridge used in previous getter-pump

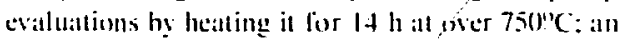
atcivalted-uranium trap was used to present residual tritium driven off by heating from entering the at mosphere. When the dynamic pressure reatched $5 x$ $10^{-4}$ Torr. the uranium trap was isolated and the cartridge was pumped on directly usinge a mercury diffusion pump until the pressure reached $2.3 \times$ $10^{-8}$ Torr. The eartridge wils then isolated under vatuum until it was loaded with tritium.

Figure 2 shows the sistem used to loid the getter-pump cartridge and analyze the residual gas after loading. The calibrated manifold wals filled with $96.69 \%$, tritiun to the pressure that would give at cartridge loading of $750 \mathrm{Ci}$ : all apparattus was at ambicut temperature. Within $30 \mathrm{~min}$ after loading. we analyed the residual gas in the maniluld with at UTI-100 C residual-gas analyar: it showed thatt the gats Wats essentially Holimm-3. the product of $\mathrm{T}_{2}$

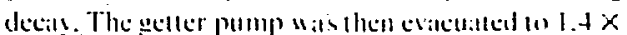
$10^{-5}$ Torr and istlatled.

Befiere remowing the getter eartridge from the lording system, the activity level of the gas a wer the eartridge was measured using an ion chamber. The manifold, lines, and pump were tilled with dry argon (1-2 ppm (s) sater) 11 760) Torr and the argon circulated through the system and ion chamber using a metal bellows pump. The ion chamber readings (corrected for the areon carricr gats) in-" dicalted that about $9 \mathrm{mCi}$ of tritium wats in the gats in the getter punip when it was isolatted. Howerer. becaltse the system and ion chamber were severely contaminated from previous work. we believe this reidling uas erroncous." Afler the ion chamber readings were made. the argon pressure was increased 16 790 Torr. the getler pump bitco " ats closed, and the pump was removed from the, 


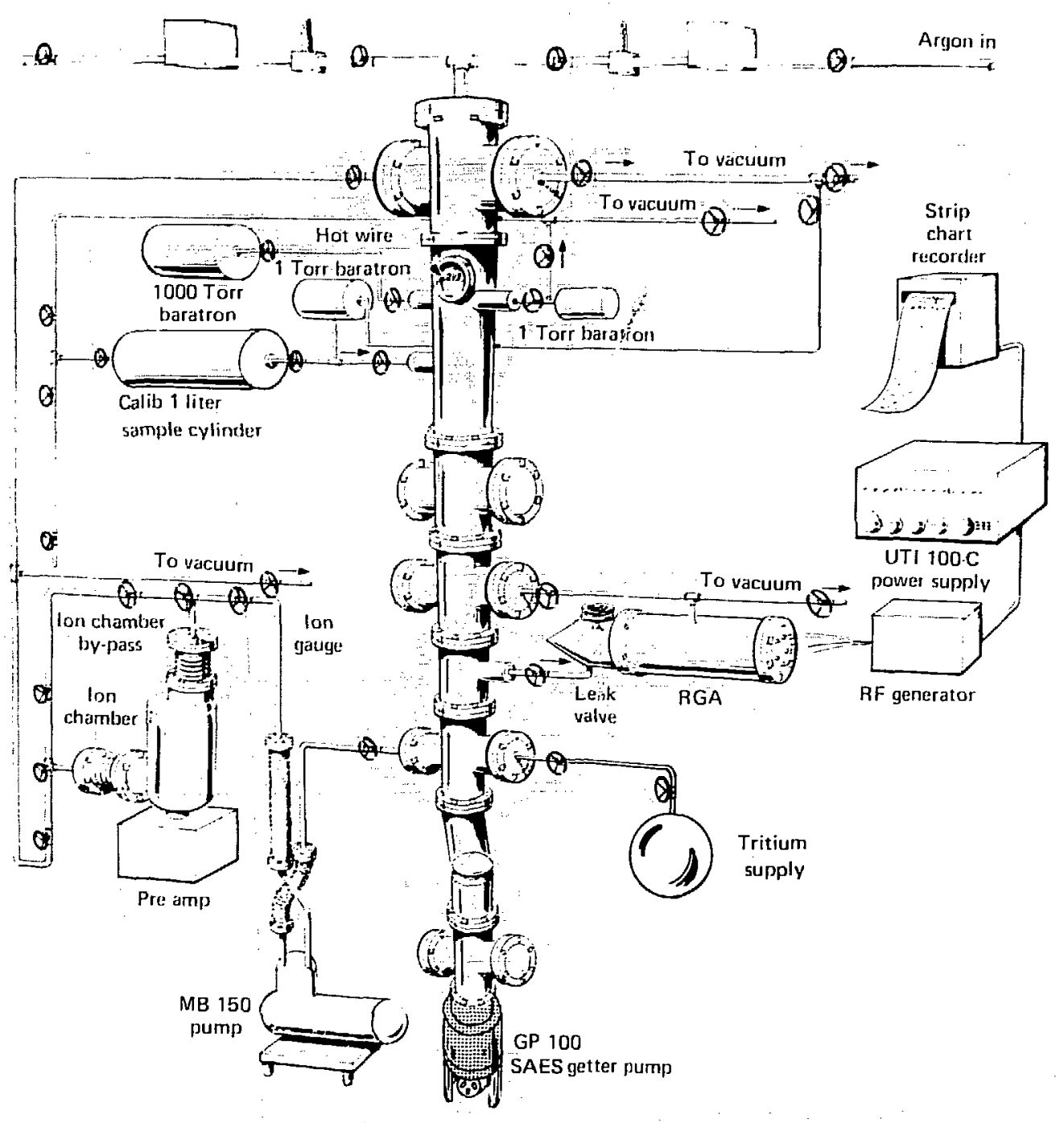

HIC. 2. Calibrated manifold system used to load getter-pump cartridge and analyze residual gas after loading.

manifold and transferred to the intertatmosphere bos lor disas iembly and remosil of the catrtridec.

The atcivity in the inert-atmosplute hox wats measured asing two ion chambers separated by a molecular sieve bed. The total alctivity (tritium and tritiated water) was meatsured in the lirst ehamber: the gats simple wits then pitsed through the mesleculat sieve hed w remose water sapur. and the attivity of he tritium gas was measured in the second thamber.

A previous experience prompled us to delermine whether the aetivit! meisured in an itiert-

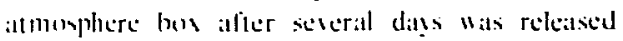
from the cartridges or from the other pump components stured in the hax. Mi remored and isolated

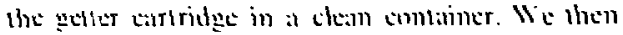


reassembled the pump body and stored all contaminated parts inside it so that a separale activity meatsurement coulal he made later (sec Fig. 3). During these matnipulatims, about $3 \mathrm{mCi}$ of tritium aclivity was relustsed in the inerl-atmosphere box, about 80\% of which was trititm gas.

Another yuestion we hoped to answer was whether the Zr-Al alloy would releatse tritium all a higher rate than predicted on the hasis of dissociation pressure alone. We removed the sealed cartridge container from the inert-itmosphere hox, and, using the same tritium monituring system as before, measured the activity releated over a 5 -h peried as the catreridge container was purged with dry argon. As in the experiment above, most of the ativity releaned was attributable to tritium gas. The tulal activity measured during this period was : $5(0)$ $\mu \mathrm{Ci}$, which corresponds to $0.5 \mu \mathrm{Ci} / \mathrm{Ci}$ on the calrtridge over $8 \mathrm{~h}$. After this measurement, the getter cartridge was isolated under dry argon.

We then measured the level of tritium released when the cartridge was exposed to moist air. The cartridge container was placed in a maintenance enclosure equipped with at tritium montoring system, pressure sensors. moisture monitors, and a tritiumremoval system (Fig. 4). A diaphragm pump and nowmeter were attached to the cartridge container, and moist air (6000-7000 $\mathrm{ppm}$ (v) water) was pumped at about $91 / \mathrm{min}$ through the cartridge container, which had a free volume of neatrly I litre. The ativity level in the enclosure increased to 5.77 $\mathrm{mCi} / \mathrm{m}^{3}$ in $16 \mathrm{~min}$. After $20 \mathrm{~min}$, the activity level begaln to drop becaluse of the removal of tritiated water by the molecular sieve hed in the monitoring system. After $66 \mathrm{~min}$. the getter cartridge was isolated under an atmosphere of moist air, and the tritium-removal system of the test enclusure was turned on. The total activity released during this $66-$ min exposure was $30.4 \mathrm{mCi}$.

After we began this experiment, we discovered that the second ion chamber had a bias that prevented accurate measurement of tritium released as $T_{2}$. Because of this, we operated the iun chambers in parallel rather than in series, and, by comparing the two readings, we estimated that at least $80 \%$ of the tritium released was in the form of tritiated water.

After the cartridge had been stored under moist air for about $24 \mathrm{~h}$, it was again exposed to moist air flowing at about $91 / \mathrm{min}$. To prevent removal of tritiated water by the molecular sieve bed in the monitoring system, the bed was bypassed during

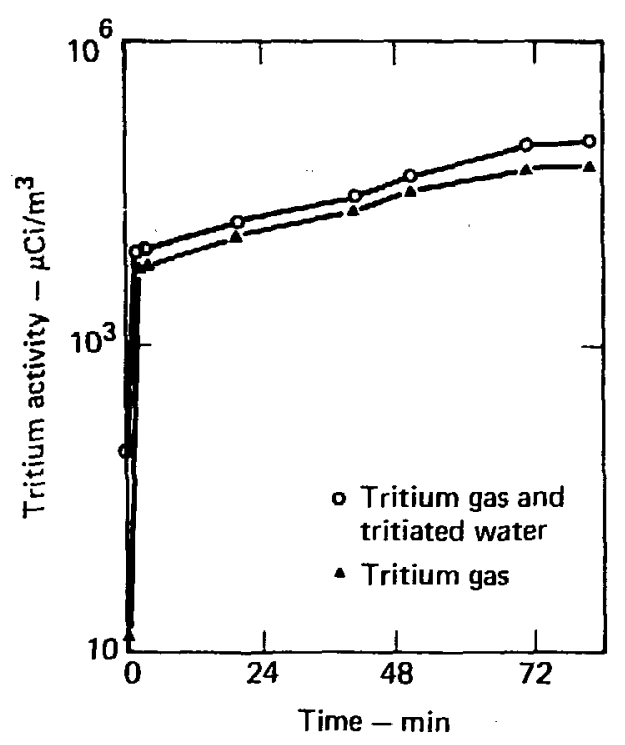

FIC. 3. Tritium activity of getter pump body and all contaminated parts measured after storage under argon for one week; total tritium release was about $9.8 \mathrm{mCi}$, about $81 \%$ of which was tritium gas.

this exposure. The activity levels measured in the enclosure were ten times lower than those observed on the previous day. (These readings included the ativity released during the storatge period.) After 12 $\mathrm{min}$, the measured tritium release rate wats about 5.5 ${ }_{\mu} \mathrm{Ci} / \mathrm{min}$. Because of the large enclosure volume $\left(5.46 \mathrm{~m}^{3}\right)$. small variations in ion chamber readings resulfed in large fluctuations in the apparent tritium releatse rates, e.g.. the rate varied between I.6 and 11 $\mu \mathrm{Ci} / \mathrm{min}$ during the latter part of the exposure. After $33 \mathrm{~min}$, the exposure was terminated and the cartridge was again slored under an almosphere of moist air. A total of $2.5 \mathrm{mCi}$ of tritium wats released during this exposure.

Because the maintenance enclosure was needed for other experiments and because the tritium release rates were so low, we removed the cartridge in its container and attempted to measure the release rates using other monitoring systems. Unfortunately, because of a combination of factors, the results of these measurentents were not entirely siltisfactory.

To test the effect of lower relative-humidity levels on the release rate, we made four runs with 


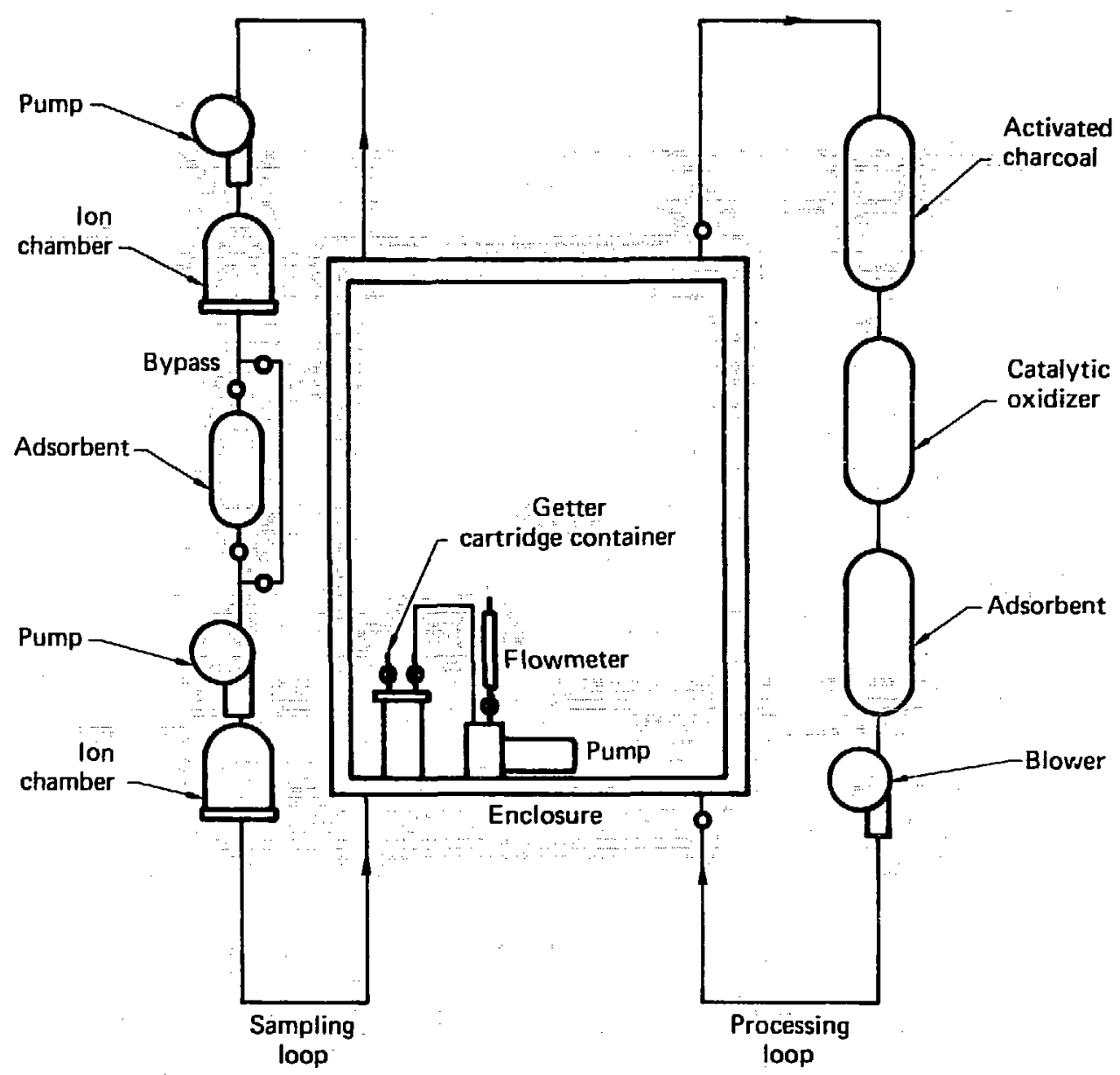

FIG. 4. Maintenance enclosure used for moist-air exposures. This system was equipped with a tritium monitoring system, pressure sensors, moisture monitors, and a tritium-removal system.

dry air ( $3.3 \mathrm{ppm}(v)$ water). We used a monitoring system, similar to the one described in Fig. 4, that consisted of two ion chambers separated by a molecular sieve bed with a provision to bypass the sieve bed if desired; the system was open to the atmosphere and vented into a fume hood. Figure 5 shows a typical run; nearly $80 \%$ of the activity was attributable to tritium gas. During one of these runs, we aiso varied the flow rate; although we expected the tritium concentration to increase as the flow rate decreased, Fig. 6 shows that changing the flow rate did not change the measured activity levels.
The final moist-air exposure was also made using this open system. After $500 \mathrm{~h}$ had elapsed, the tritium release rates were very low and flow rates had to be reduced to extremely low values to see any significant changes in ion chamber readings: unfortunately, it was almost impossible to keep such low flow rates constant. We continued the final exposure for over $770 \mathrm{~h}$. We ohserved the majur change in releatse rate during the first $100 \mathrm{~h}$; subsequent changes were small and fluctuated with changes in relative humidity (Fig. 7). Figure 8 shows the observed changes in release rate over the entire exposure period of about $1200 \mathrm{~h}$. 


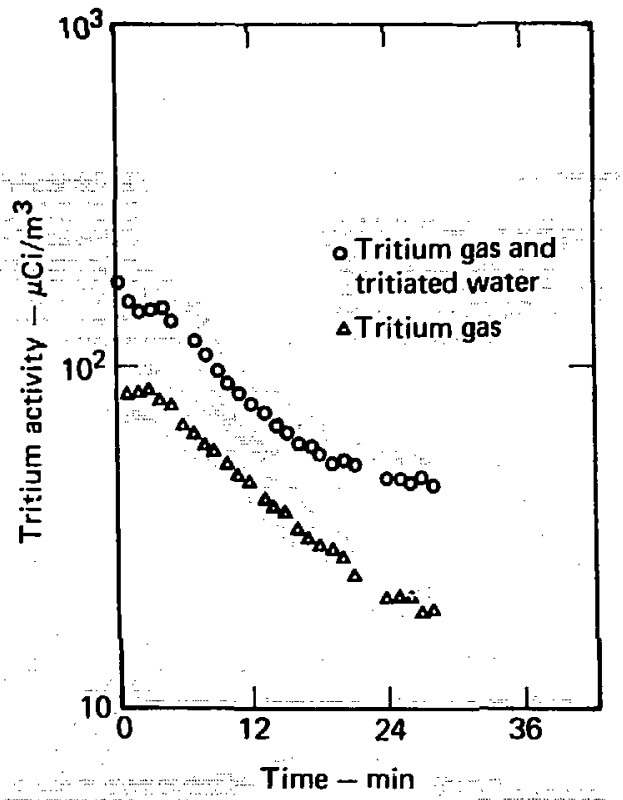

FIG. 5. Ion chamber readings for typical run (No. 8) of cartridge exposed to dry air (3.3 ppm (v) water); nearly $80 \%$ of the activity was attributable to tritium gas. The cartridge had been stored under dry air for about $15 \mathrm{~h}$; the air flow was $740 \mathrm{~cm}^{3} / \mathrm{min}$, and the container volume was $930 \mathrm{~cm}^{3}$.

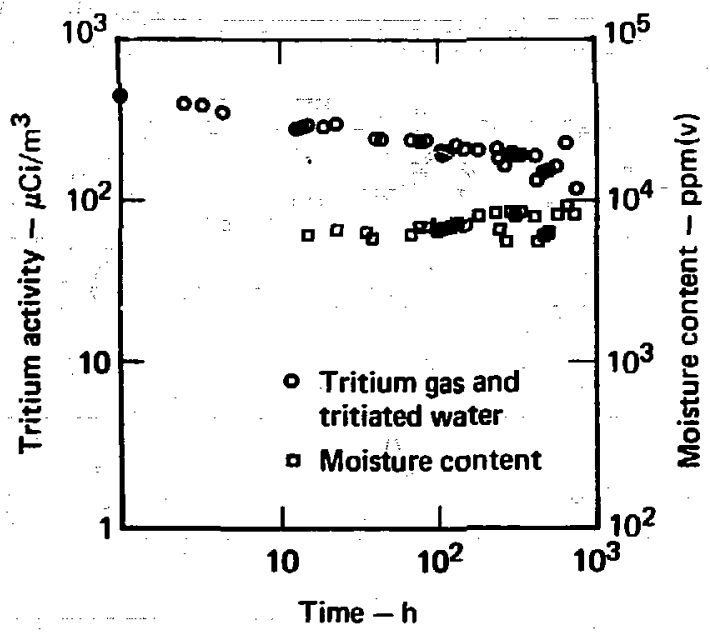

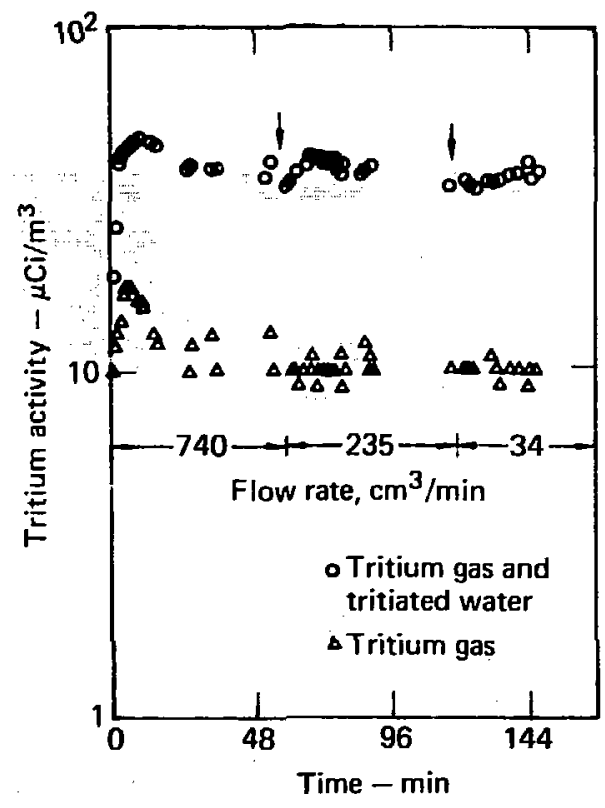

FIG. 6. Ion chamber readings for run No. 9 (cartridge exposed to dry air); the flow rate was varied during this run, but no significant chianges in the activity levels were observed. The cartridge had been stored under dry air for about $5.6 \mathrm{~h}$.
FIG. 7. Ion chamber readings for run No. 11 (cartridge exposed to moist air); the major change in release rate occurred during the first $100 \mathrm{~h}$; subsequent changes were small and nuctuated with changes in relative humidity. The air nlow was 235 $\mathrm{cm}^{3} / \mathrm{min}$. 


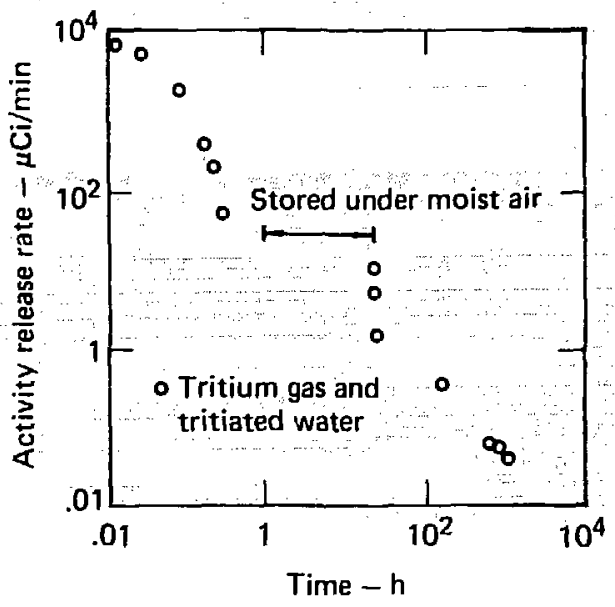

CONCLUSIONS

Our observations showed that the initial tritium release from a loaded C- 100 getler cartridge exposed to moist air is rapid but that the amount released represents only a small fraction of the cartridge loading. More than $72 \%$ of the total tritium released during the exposure was released during the first $4 \mathrm{~min}$; the release measured in $66 \mathrm{~min}$ amounted to less than $0.005 \%$ of the cartridge loading. As predicted by Singleton and Griffith, the release rale decrealsed rapidly with time; after
FIC. 8. Change in release rate over the entire exposure period of about $1200 \mathrm{~h}$.

\section{RECOMMENDATIONS}

The C-500 getter puinps proposed for use in the TFTR will contain significantly lirger getter elements with approximately five times the active surface area of the $C-100$ pump cartridges we tes:ed. "If we assume equal loading and release proportional to the active surface area, we would expect the initial release each C-500 pump to be about $0.15 \mathrm{Ci}$ if the getter is exposed to air. If an entire array of 12 more that $1200 \mathrm{~h}$, the total tritium activity released by the cartridge amounted to less than $0.1 \mathrm{Ci}$ (about 0.0 ' ' $\%$ of the cartridge louding).

A comparison of our data with the reported release rate of tritium from titanium trilide sources under dry air ${ }^{5}$ indicates that the release ralte of the $\mathrm{Zr}-\mathrm{Al}$ alloy is significantly lower. However, there are insufficient data to demonstrate that such a comparison is valid.

\section{ACKNOWLEDGMENTS}

We thank other members of the tritium facility staff for their assistance on this project. Dan Disch and Lyall Miller provided the electronic support required to make the cartridge-loading system punps were exposed simultaneously, about $2 \mathrm{Ci}$ would be released almost immediately. Because most of the release would be tritiated water and because the biological uptake of tritiated water is much morc rapid than that of tritium gas, we recommend that special techniques and handling fixtures be used to prevent or reduce radiation exposures of operating personnel. 


\section{REFERENCES}

1. R. G. Hickman. "Tritium Problems in Fusion Reactor Systems," in Proc. Symposium on Tritium Technology Related to Fusion Reactor Systems (Miamishurg, Ohio, 1974), ERDA-50. 1975, pp. 76-86.

2. A Barosi, $T$ A Girogi, and L Rosai, "Characteristics of SORB-AC Non-Evaporable Getter Cartridges and Their Polential Use in Fusion Reictors, in Proc of Int Conference on Radianion Effects and Tritium Technology for Fusion Reaciors (Gailinburg, Tenn, 1975), NTIS Conf-750989, IV 203 (1976).

3. Tokomak Fusion Test Reactor Facilities, Final Enwrommental Statement, U.S. Energy Restarch and Development Administration, ERDA-1544, Princeton Plisma Physies Laboratory, Princeton, N.J. (1975).

4. M. F. Singleton and C. M. Griflitb, Evaluation of a Nonevaporable Genter Pump for Tritium Handling in the Tokomak Fusion Test Reactor, Lawrence Livermore Laboratiory, Livermore, Calif., UCR L-52584 (1978).

5. J. A. B. Gibson, The Possible Radiological Hazard from Tritium Sources Absorbed on Titanium, United Kingdom Atomic Energy Authority Research Group, Atomic Energy Rescarch Establishment, Harwell, Berks, Greud : Britain $(1963)$.

6. "Westinghouse Datil Sheet B-439," Westinghouse Electric Corp., Horseheads, N.Y. (1978). 